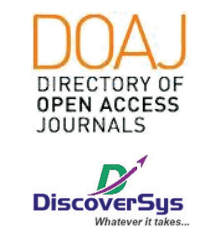

Published by DiscoverSys

\title{
Prevalensi dan gambaran karakteristik penderita kanker payudara di poliklinik bedah onkologi RSUP Sanglah, Bali, Indonesia tahun 2016
}

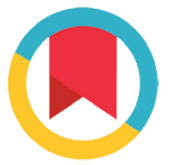

CrossMark

I Dewa Ayu Putu Mas Narisuari, ${ }^{1 *}$ Ida Bagus Tjakra Wibawa Manuaba²

\section{ABSTRACT}

Background: Breast cancer is a malignancy originating from breast tissue. In Indonesia, the prevalence rate of breast cancer is $0.5 \%$ or around 61,628, and the incidence of breast cancer in Bali reached $0.6 \%$ in 2013 . The aetiology of breast cancers are multifactorial, and the main factor is still unknown. This study aims to determine the prevalence and characteristics of breast cancer patients in the Sanglah General Hospital oncology surgery clinic.

Methods: This study was a descriptive cross-sectional study. The sample used was a patient suffering from breast cancer who visited Sanglah General Hospital's oncology surgical clinic, both outpatient and hospitalization in 2016 and was willing to submit informed consent. Variables assessed in this study were age, education level, jobs, symptoms, history of breast cancer, the staging of breast cancer, and type of medication. Data were analyzed using SPSS version 17 for Windows. Results: The results showed the dominant sociodemographic characteristics of respondents in the age range $41-50$ years as many as 27 people (42.18\%), had an education level equivalent to senior high school 27 people (42.18\%), worked as private employees, and there were 23 entrepreneurs (35.93\%) from 62 samples. Other characteristics obtained 55 people $(85.94 \%)$ respondents experienced initial symptoms of lumps in the breast, 13 people (20.31\%) respondents had a family history of breast cancer. A total of 13 patients (20.31\%) claimed to use herbal medicine, and $7(10.94 \%)$ admitted to undergoing alternative treatment other than treatment in Sanglah General Hospital, Bali, Indonesia. Only $43.75 \%$ decided to seek treatment for their own sake. The majority of patients, as many as 41 people (64.06\%) were diagnosed in stage III.

Conclusion: People living with Breast cancer at Sanglah Hospital have a younger age compared to the majority of breast cancer sufferers in the world. Lack of knowledge of women about breast cancer itself is one of the causes.

Keywords: breast cancer, prevalence, characteristics.

Cite This Article: Narisuari, I.D.A.P.M., Manuaba, I.B.T.W. 2020. Prevalensi dan gambaran karakteristik penderita kanker payudara di poliklinik bedah onkologi RSUP Sanglah, Bali, Indonesia tahun 2016. Intisari Sains Medis 11(1): 183-189. D0I: 10.15562/ism.v11i1.526

\section{ABSTRAK}

${ }^{1}$ Mahasiwa Program Studi Pendidikan Dokter, Fakultas Kedokteran, Universitas Udayana, Bali, Indonesia

Departemen Bedah, Divisi Onkologi, Fakultas Kedokteran, Universitas Udayana, RSUP Sanglah, Bali, Indonesia

\section{${ }^{*}$ Korespondensi:}

I Dewa Ayu Putu Mas Narisuari; Program Studi Pendidikan Dokter, Fakultas Kedokteran, Universitas Udayana, Bali, Indonesia; dewaayunarheswari@gmail.com

Diterima: 15-06-2019 Disetujui: 11-03-2020 Diterbitkan: 24-03-2020
Latar Belakang: Kanker payudara adalah keganasan yang berasal dari jaringan payudara. Di Indonesia kanker payudara merupakan kenker dengan angka prevalensi kejadian 0.5\% atau sekitar 61.628 dan kejadian kanker payudara di Bali mencapai 0.6\% pada tahun 2013. Penyebab kanker payudara termasuk multifaktorial yang belum diketahui penyebab utamanya. Penelitian ini bertujuan untuk mengetahui distribusi prevalensi gambaran karakteristik penderita kanker payudara di poliklinik bedah onkologi RSUP Sanglah.

Metode: Penelitian ini merupakan penelitian observasional deskriptif cross-sectional. Sampel yang digunakan merupakan pasien yang menderita kanker payudara yang mengunjungi poliklinik bedah onkologi RSUP Sanglah baik rawat jalan maupun rawat inap pada tahun 2016 dan bersedia mengisi informed consent. Variabel yang dinilai dalam penelitian ini adalah usia, tingkat pendidikan, pekerjaan, gejala, riwayat kanker payudara, stadium kanker payudara, dan jenis pengobatan. Data dianalisis menggunakan SPSS versi 17 untuk Windows.
Hasil: Hasil penelitian menunjukkan karakteristik sosiodemografi responden dominan berada pada rentang usia 41-50 tahun sebanyak 27 orang (42,18\%), memiliki tingkat pendidikan setara Sekolah Menengah Atas (SMA) sebanyak 27 orang (42,18\%), bekerja sebagai karyawan swasta dan wiraswasta sebanyak 23 orang $(35,93 \%)$ dari 62 orang sampel. Karakteristik lain yang diperoleh, sebanyak 55 orang $(85,94 \%)$ responden mengalami gejala awal berupa benjolan pada payudara, responden memiliki riwayat keluarga dengan kanker payudara sebanyak 13 orang (20,31\%). Sebanyak 13 penderita (20,31\%) mengaku menggunakan pengobatan herbal, dan 7 (10,94\%) mengaku menjalani pengobatan alternatif selain pengobatan di RSUP. Hanya sebesar 43,75\% yang memutuskan berobat karena keinginan sendiri. Mayoritas penderita terdiagnosis padaa stadium III yaitu sebanyak 41 orang $(64,06 \%)$.

Kesimpulan: Penderita kanker payudara di RSUP Sanglah memiliki usia yang lebih muda jika dibandingkan dengan mayoritas penderita kanker payudara di dunia. Kurangnya pengetahuan wanita terhadap kanker payudara itu sendiri merupakan salah satu penyebabnya. 
Kata kunci: kanker payudara, prevalensi, karakteristik.

Cite Pasal Ini: Narisuari, I.D.A.P.M., Manuaba, I.B.T.W. 2020. Prevalensi dan gambaran karakteristik penderita kanker payudara di poliklinik bedah onkologi RSUP Sanglah, Bali, Indonesia tahun 2016. Intisari Sains Medis 11(1): 183-189. D0I: 10.15562/ism.v11i1.526

\section{PENDAHULUAN}

Kanker merupakan suatu penyakit yang menjadi ancaman bagi kesehatan masyarakat di seluruh Negara di dunia. Di Indonesia, peningkatan angka kejadian kanker cukup meresahkan, salah satunya adalah kanker payudara. Kanker payudara (Carcinoma mammae) adalah suatu keganasan yang menyerang kelenjar air susu, saluran kelenjar dan jaringan penunjang payudara. Kanker payudara memperlihatkan proliferasi keganasan sel epitel yang membatasi duktus atau lobus payudara. ${ }^{1}$

Kanker payudara menduduki peringkat kedua setelah kanker leher rahim yang menyerang kaum wanita di seluruh dunia. Menurut GLOBOCAN 2012 angka kejadian kanker payudara tertinggi di ASEAN dimiliki oleh Indonesia yaitu sebesar 48.998 dan 40.3 per 100.000 wanita (AISR/Age Standardize Incidence Rate), diikuti oleh Filipina sebesar 18.327 (47), Thailand 13.653 (29.3) dan Malaysia sebanyak 5.410 (38.7). ${ }^{2}$ Di Indonesia kanker payudara merupakan kanker dengan angka prevalensi kejadian $0.5 \%$ atau sekitar 61.628 dan prevalensi angka kejadian kanker payudara di Bali mencapai $0.6 \%$ pada tahun $2013 .^{2}$

Penyebab kanker payudara termasuk multifaktorial yang penyebab utamanya belum diketahui dengan jelas. Ada beberapa faktor yang diperkirakan memiliki pengaruh terhadap kanker payudara, diantaranya yaitu usia, usia melahirkan anak pertama, menarche dini, menopause terlambat, riwayat menderita tumor jinak payudara, riwayat menyusui, riwayat melahirkan, paparan radiasi sebelumnya, penggunaan hormon, riwayat keluarga, obesitas, kanker pada salah satu payudara, konsumsi makanan tinggi lemak, alkohol, perokok, dan kepadatan payudara. ${ }^{2}$

Tanda dan gejala kanker payudara seperti adanya benjolan pada payudara, adanya cairan atau perubahan dari puting susu, nodul, ataupun perubahan kulit sekitar payudara. Berdasarkan hasil penelitian tahun 2009 ditemukan bahwa sebagian besar wanita yang terdiagnosa stadium lanjut kanker payudara pada awalnya menemukan adanya benjolan di payudara namun menganggap benjolan tersebut sebagai satu hal yang biasa saja. ${ }^{2}$ Tingginya angka kematian yang disebabkan oleh kanker payudara disebabkan karena kurangnya kesadaran penderita akan gejala yang dialami serta pengetahuan yang kurang $(71,43 \%)$ terkait tanda, pemeriksaan dini dan waktu pemeriksaan dini. Terkait dengan sikap dalam melakukan pemeriksaan dini terdapat hampir 100\% mereka yang menderita stadium lanjut memiliki sikap negatif. Berdasarkan permasalahan tersebut dilakukan penelitian yang bertujuan untuk mengetahui gambaran karakteristik dari penderita kanker payudara di poliklinik bedah onkologi RSUP Sanglah Denpasar.

\section{METODE PENELITIAN}

Penelitian ini merupakan penelitian deskriptif dengan menggunakan desain potong lintang terhadap 64 responden penelitian. Sampel yang digunakan merupakan semua pasien yang menderita kanker payudara yang mengunjungi poliklinik bedah onkologi RSUP Sanglah baik rawat jalan maupun rawat inap pada tahun 2016 dan bersedia mengisi persetujuan tertulis atau informed consent.

Penelitian ini menggunakan rekam medis dan wawancara langsung menggunakan kuisioner yang telah diuji validitas dan reliabilitasnya. Hasil yang didapat selanjutnya diolah dan dipaparkan berupa tabel distribusi frekuensi, lalu dianalisis secara deskriptif menggunakan persentase untuk dapat menggambarkan karakteristik dari penderita kanker payudara di poliklinik bedah onkologi RSUP Sanglah Denpasar. Adapun variabel yang dinilai pada penelitian ini adalah karakteristik sosiodemografis (usia, tingkat Pendidikan, dan jenis pekerjaan) dan karakteristik responden berdasarkan kusioner (tanda dan gejala awal, riwayat keluarga, riwayat pengobatan, alasan berobat, rentang waktu berobat, stadium kanker payudara, maupun metastasis kanker). Seluruh data yang diperoleh kemudian dianalisis menggunakan piranti lunak SPSS versi 17 untuk Windows.

\section{HASIL PENELITIAN}

Telah dilakukan analisis data dan diperoleh distribusi proporsi dari penderita kanker payudara berdasarkan sosiodemografi usia, pendidikan dan pekerjaan (Tabel 1). Usia penderita kanker payudaara terbesar beradaa pada rentang usia 41-50 tahun yaitu sebanyak 27 orang $(42,18 \%)$, diikuti oleh usia diatas 50 tahun, yakni sebanyak 19 orang (29,68\%). Penderita kanker payudara paling sedikit berasal dari wanita dengan usia dibawah 30 tahun, yaitu sebanyak 4 orang $(6,25 \%)$ (Tabel 1).

Mayoritas penderita kankel payudara memiliki tingkat pendidikan setara Sekolah Menengah Atas sebanyak 27 orang $(42,18 \%)$, diikuti oleh jumlah 
Tabel 1 Karakteristik penderita kanker payudara berdasarkan sosiodemografi di Poliklinik Bedah Onkologi RSUP Sanglah tahun 2016

\begin{tabular}{lcc}
\hline Variabel & Frekuensi (N=64) & Persentase (\%) \\
\hline Usia (tahun) & & \\
$\quad<30$ & 4 & 6,25 \\
$30-40$ & 14 & 21,87 \\
$41-50$ & 27 & 42,18 \\
$>50$ & 19 & 29,68 \\
Pendidikan & & \\
$\quad$ Tidak Sekolah & 7 & 10,93 \\
Sekolah Dasar & 11 & 17,18 \\
Sekolah Menengah Pertama & 12 & 18,75 \\
$\quad$ Sekolah Menengah Atas & 27 & 42,18 \\
$\quad$ Perguruan Tinggi & 7 & 10,93 \\
$\quad$ Pekerjaan & 15 & 23,43 \\
Ibu Rumah Tangga & & \\
$\quad$ Pegawai Negeri Sipil & 9 & 10,60 \\
Swasta & 23 & 35,93 \\
$\quad$ Lain-lain & 17 & 26,56 \\
\hline
\end{tabular}

Tabel 2 Karakteristik penderita kanker payudara di Poliklinik Bedah Onkologi RSUP Sanglah tahun 2016

\begin{tabular}{lcc}
\hline Parameter & Frekuensi (N=64) & Persentase (\%) \\
\hline Tanda dan Gejala Awal & & \\
Benjolan atau Penebalan & 55 & 85,94 \\
Perubahan Bentuk dan Ukuran & 0 & 0,00 \\
Kerutan & 0 & 0,00 \\
Keluar Cairan & 0 & 0,00 \\
$\quad$ Nyeri Menetap & 2 & 3,13 \\
Kemerahan atau Bengkak & 3 & 4,69 \\
$\quad$ Retraksi Putting & 1 & 1,56 \\
Gatal, ruam, bersisik & 2 & 3,13 \\
Lainnya & 0 & 0,00 \\
Riwayat Keluarga & & \\
Ada & 10 & 15,62 \\
Tidak & 54 & 84,37 \\
Riwayat Pengobatan Lain & & \\
Ada & & 20,31 \\
$\quad$ Herbal & 13 & 10,94 \\
Alternatif & 7 & 68,75 \\
Tidak & 44 & \\
Alasan Berobat & & 56,25 \\
Disarankan & 36 & 43,75 \\
Sendiri & 28 & 32,81 \\
Rentang Waktu & & 67,19 \\
Segera & 15 & \\
Tidak Segera & 39 & \\
\hline
\end{tabular}


Tabel 2 Continue

\begin{tabular}{lcc}
\hline Parameter & Frekuensi $(\mathbf{N}=\mathbf{6 4 )}$ & Persentase (\%) \\
\hline Stadium & 0 & 0,00 \\
I & 13 & 20,31 \\
II & 41 & 64,06 \\
III & 10 & 15,62 \\
IV & & \\
Metastasis & 2 & 3,12 \\
Ya & 62 & 96,88 \\
Tidak & \multicolumn{2}{c}{}
\end{tabular}

penderita yang memiliki tingkat pendidikan setara Sekolah Menengah Pertama sebanyak 12 orang $(18,75 \%)$. Sedangkan, penderita yang tidak bersekolah memiliki jumlah yang sama dengan penderita yang mengenyam tingkat Perguruan Tinggi, yakni masing-masing 7 orang $(10,93 \%)$ (Tabel 1$)$.

Mayoritas penderita bekerja sebagai karyawan swasta dan wiraswasta, yaitu sebanyak 23 orang $(35,93 \%)$, sedangkan jumlah penderita yang memiliki pekerjaan sebagai Pegawai Negeri Sipil (PNS) memiliki jumlah terendah yaitu hanya sebanyak 9 oranng (10,60\%) (Tabel 1).

Karakteristik penderita kanker payudara berdasarkan kuesioner yang telah diisi, mayoritas penderita mengatakan bahwa gejala paling awal yang mereka rasakan adalah terdapatnya benjolan pada payudara, yaitu sebanyak 55 orang $(85,94 \%)$ dari total 64 responden yang diwawancara. Sedangkan, hanya terdapat 1 responden $(1,56 \%)$ yang mengaku mengalami retraksi atau masuknya bagian putting susu kearah dalam (Tabel 2).

Riwayat kanker payudara dalam keluarga merupakan salah satu faktor resiko kanker payudara. Namun pada hasil wawancara, dari 64 orang hanya sebanyak 13 orang (20,31\%) responden yang mengaku adanya anggota keluarga lain yang memiliki riwayat menderita kanker payudara (Tabel 2).

Salah satu dari informasi tambahan yang ditanyakan melalui kuisioner ini adalah ada atau tidaknya pengobatan lain yang dilakukan oleh masing-masing penderita kanker payudara. Pada tabel 2 dapat terlihat bahwa jumlah penderita yang menjalani pengobatan selain pengobatan di Rumah Sakit sebanyak 20 orang, dimana diantaranya 13 penderita $(20,31 \%)$ mengaku menggunakan pengobatan herbal, dan $7(10,94 \%)$ sisanya mengaku menjalani pengobatan alternatif (Tabel 2).

Hanya sebesar 43,75 \% dari total 64 responden atau hanya sekitar 28 orang yang memutuskan berobat karena keinginan sendiri, sedangkan 36 orang $(56,25 \%)$ sisanya memutuskan untuk menjalani pengobatan karena mendapat saran dari orang lain. Jumlah penderita yang segera memeriksakan diri hanya sebesar $23,43 \%$ atau sebanyak 15 orang. Sedangkan sisanya lebih banyak menunda untuk melakukan pemeriksaan. Hal ini bisa dilihat dari mayoritas penderita terdiagnosis padaa stadium III yaitu sebanyak 41 orang (64,06\%) (Tabel 2).

\section{PEMBAHASAN}

Pada penelitian ini berdasarkan karakteristik sosiodemografis mayoritas responden didiagnosis terkena kanker payudara pada usia 41 - 50 tahun atau sekitar 30\% dari jumlah total responden. Hal ini sesuai dengan hasil penelitian yang diungkapkan oleh Hartaningsih dan Sudarsa tahun 2013, bahwa dari 876 kasus kanker payudara di RSUP Sanglah dari tahun 2002 - 2012 mayoritas usia penderita kanker payudara berkisar pada rentang umur 41-50 tahun yaitu sebesar 45,2\%. ${ }^{3}$ Namun hal berbeda ditemukan pada penderita kanker payudara di Inggris, dimana mayoritas penderita yang terdiagnosis pada tahun 2012-2014 berada pada usia lebih dari 65 tahun yaitu sekitar $48 \%$. Hal yang sama juga ditemukan pada penderita kanker payudara di Amerika Serikat dimana puncak insiden penderita kanker payudara berada pada usia 70 tahun. Hal tersebut menunjukan adanya perbedaan antara usia penderita kanker payudara di Asia khususnya Indonesia dimana mayoritas penderita kanker payudara berada pada usia yang terbilang lebih muda yaitu rentang usia 40-50 tahun, sedangkan mayoritas penderita kanker payudara di Inggris dan Amerika Serikat berada pada usia tua yaitu diatas 60 tahun.

Ada beberapa penelitian yang mengemukakan beberapa kemungkinan terdapatnya kanker payudara pada usia lebih muda. Salah satu diantaranya dikemukakkan dalam jurnal penelitian bahwa wanita dengan mutasi gen BRCA1/2 memiliki kemungkinan lebih besar untuk menderita kanker payudara pada usia muda jika dibandingkan dengan wanita tanpa mutasi gen. Pada jurnal tersebut juga dikemukakan bahwa hal yang sama 
ditemukan pada wanita Afrika, dimana mereka menderita kanker payudara pada usia yang lebih muda. ${ }^{4}$ Disamping mutase gen BRCA1/2, beberapa studi sebelumnya juga menunjukkan bahwa parameter hematologi seperti neutrophil, limfosit, platelet, dan lainnya dapat dijadikan rujukan untuk subtipe kanker payudara maupun untuk memberikan gambaran klinikopatologis. ${ }^{5,6}$

Penelitian lain yang dilakukan oleh Kim tahun 2015 menunjukkan bahwa wanita di Asia menderita kanker payudara pada usia yang lebih muda dibandingkan wanita dengan Ras Kaukasian. Penelitian ini juga menunjukkan tentang distribusi dari mutasi gen BRCA $1 / 2$ pada wanita asia yang lebih tinggi dibandingkan dengan wanita dengan ras kaukasian. Pada kanker payudara early onset tahun 2012 ditemukan bahwa dari 625 penderita kanker, ditemukan adanya mutasi gen BRCA pada 53 wanita $(8.5 \%) .^{7}$ Penelitian lain yang dilakukan di Malaysia pada tahun 2012, menunjukkan bahwa dari 100 penderita, ditemukan adanya 17 penderita yang memiliki mutasi gen BRCA.?

Jika dilihat pada tabel 2, bahwa gejala awal yang paling sering dialami oleh penderita kanker payudara adalah benjolan tanpa rasa nyeri $(85,94 \%)$ dimana skrining dengan SADARI merupakan salah satu cara deteksi dini yang tepat dan mudah. Pada penelitian yang dilakukan di Pakistan, ditemukan bahwa 39\% penyebab keterlambatan pasien untuk memeriksakan diri adalah karena gejala yang dimiliki dianggap tidak berbahaya, salah satunya adalah benjolan yang tidak nyeri. ${ }^{8}$

Namun beberapa penelitian sebelumnya menunjukkan bahwa masih rendahnya tingkat pengetahuan masyarakat tentang SADARI. Salah satunya dikemukakan pada penelitian yang dilakukan oleh Nugraha. Kurangnya pengetahuan tentang SADARI juga ditunjukkan dari hasil penelitian yang dilakukan di RSUP Sanglah dan RS Prima Medika pada November 2012, bahwa hanya 13\% dari responden yang mengetahui tentang SADARI, dan hanya 50\% dari responden yang tahu tentang SADARI yang pernah melakukannya. ${ }^{9}$

Hal itu menunjukkan bahwa tingkat pendidikan yang dimiliki oleh penderita kanker payudara tidak serta merta menunjukkan tingkat pengetahuan yang dimiliki oleh penderita tentang kanker payudara. Selain itu, pada hasil penelitian yang dapat dilihat pada tabel 2, menunjukkan bahwa jumlah penderita yang segera memeriksakan diri setelah menyadari adanya perubahan pada payudara hanya sebanyak 21 orang atau sekitar $32,81 \%$. Pada salah satu penelitian yang dilakukan di Uganda, mengatakan bahwa secara umum penderita kanker payudara menunda pemeriksaan selama 29 bulan. $^{10}$
Sedangkan penelitian lain yang dilakukan di Pakistan menunjukkan bahwa $70 \%$ dari responden penelitian datang untuk memeriksakan diri dalam kurun waktu 1 tahun, dan sisanya sebesar $30 \%$ memutuskan untuk datang dalam kurun waktu 4 tahun. Hal ini terlihat berbeda dengan penelitian sebelumnya yang dilakukan di Selandia Baru yang menunjukan bahwa $40 \%$ responden hanya menunda dalam kurun waktu 40 hari. Hal tersebut menunjukkan adanya perbedaan tingkat kewaspadaan pasien terhadap penyakitnya. ${ }^{11}$

Keterlambatan pasien dalam memeriksakan diri juga dapat dilihat dari stadium pasien saat diagnosa awal. Mayoritas pasien datang memeriksakan diri ketika sudah berada pada stadium III yaitu sebanyak 41 orang $(64,06 \%)$. Hal ini sesuai dengan penelitian sebelumnya yang dilakukan oleh yang menunjukkan bahwa sebanyak $48,2 \%$ dari 166 penderita datang pada stadium III. ${ }^{12}$ Hal lain yang juga ditemukan adalah, dari 64 responden, hanya 2 orang yang mengaku memiliki gejala mestastasis.

Tentunya keterlambatan pasien datang untuk memeriksakan diri tidak hanya dipengaruhi oleh tingkat pengetahuan saja. Ada berbagai macam faktor yang memengaruhi keputusan pasien untuk datang memeriksakan diri. Sebagian besar responden di RSUP Sanglah mengatakan bahwa mereka sebenarnya telah menyadari adanya perubahan yang terjadi pada payudara, namun karena beberapa alasan tertentu akhirnya memutuskan untuk menunda pemeriksaan dan pengobatan. Penelitian yang dilakukan oleh Clegg di Ghana tahun 2009 menunjukkan bahwa penyebab keterlambatan pasien untuk dating memeriksakan diri ke pelayanan kesehatan adalah konsultasi medis sebelumnya, ketidakpedulian terhadap kondisi diri, takut akan operasi, penggunaan CAM, ketidakmampuan finansial, dan keyakinan atau budaya. ${ }^{13}$

Faktor lainnya adalah biaya. Namun jika dilihat dari mayoritas pekerjaan yang dimiliki oleh responden adalah karyawan swasta dan wiraswasta yaitu sebanyak 35,96\%. Terlebih lagi menurut survei Kesehatan Dasar tahun 2013, Bali merupakan daerah dengan kepemilikan jaminan kesehatan terbesar kedua setelah Aceh.

Faktor yang sebenarnya tidak boleh dilupakan adalah budaya. Bali merupakan daerah yang sangat kental akan budaya. Hal ini tentunya memengaruhi persepsi masyarakat terhadap pengobatan suatu penyakit, kanker payudara khususnya. Sebagian besar responden mengungkapkan bahwa salah satu alasan menunda pengobatan adalah kepercayaan terhadap hal spiritual, selain itu ketakutan akan tindakan pengobatan juga merupakan faktor penyebab sebagian besar responden memutuskan untuk menunda pengobatan ke Rumah Sakit. 
Pada hasil penelitian yang tertera dalam Tabel 2 terlihat bahwa sebanyak 20 orang responden memutuskan untuk menjalani pengobatan non medis terlebih dahulu. Hal serupa juga ditemukan pada penelitian sebelumnya yang dilakukan sebelumnya di RSUP Sanglah dimana sebanyak $46 \%$ dari penderita yang menjadi subjek penelitian mengaku pernah mencoba menjalani pengobatan alternatif sebelum akhirnya memutuskan untuk memeriksakan diri ke RSUP Sanglah. ${ }^{3,9}$ Memang seakan terdapat adanya penurunan penggunaan CAM pada penderita kanker payudara di RSUP Sanglah. Hal ini dapat berarti adanya peningkatn kesadaran masyarakat akan pengobatan kanker payudara. Namun hal tersebut juga dapat diasumsikkan bahwa masih banyak pasien yang menyembunyikan tentang penggunaan CAM pada petugas kesehatan. Seperti penelitian yang dilakukan oleh Erkeu di Etiopia, dilaporkan bahwa tingkat penggunaan CAM yang tinggi namun dilakukan secara sembunyi-sembunyi. ${ }^{14}$

Pada penelitian ini, memang tidak ditanyakan tentang alasan responden memilih CAM sebagai pengobatan terlebih dahulu sebelum memutuskan untuk berobat ke pelayanan kesehatan. Namun pada penelitian yang dilakukan sebelumnya di RSUP sanglah, ditemukan ada beberapa alasan yang dikemukakan oleh penderita kanker payudara. Alasan yang paling sering diutarakan adalah pasien memilih CAM sebagai pengobatan untuk menghindari operasi dan kemoterapi, hal lain yang menjadi alasan pemilihan CAM sebagai pengobatan adalah ketika pasien merasa telah menjalani pengobatan konvensional tapi tak kunjung sembuh, dan beberapa pasien juga mengaku lebih percaya terhadap pengobataan alternatif atau tradisional.

\section{SIMPULAN}

Penderita kanker payudara di RSUP Sanglah memiliki usia yang lebih muda jika dibandingkan dengan mayoritas penderita kanker payudara di dunia. Selain itu keterlambatan pemeriksaan dan penanganan atau pengobatan terhadap penderita kanker payudara masih menjadi masalah yang belum terselesaikan. Salah satu penyebab diantaranya adalah kurangnya pengetahuan wanita terhadap kanker payudara itu sendiri, hal ini tentunya menimbulkan beberapa masalah lain yang menghambat diagnosis dini terhadap kanker itu sendiri, yaitu kesalahan persepsi wanita terhadap kanker payudara dan pengobatan kanker payudara itu sendiri. Hal tersebut dapat dilihat dari masih tingginya penderita kanker payudara yang memutuskan untuk menjalani pengobatan alternatif terlebih dahulu sebelum memeriksakan diri ke pelayanan kesehatan.

\section{KONFLIK KEPENTINGAN}

Tidak terdapat konflik kepentingan dalam penulisan laporan penelitian ini.

\section{ETIKA PENELITIAN}

Persetujuan etik telah diperoleh dari Fakultas Kedokteran Universitas Udayana dan RSUP Sanglah, Denpasar, Bali, Indonesia sebelum penelitian berjalan.

\section{PENDANAAN}

Tidak ada

\section{KONTRIBUSI PENULIS}

Seluruh penulis memiliki kontribusi yang sama dalam penulisan laporan penelitian ini baik dari tahap penyusunan kerangka berpikir hingga interpretasi hasil dalam laporan penelitian.

\section{DAFTAR PUSTAKA}

1. Shah R, Rosso K, Nathanson SD. Pathogenesis, prevention, diagnosis and treatment of breast cancer. World J Clin Oncol. 2014;5(3): 283-298.

2. Bray F, Ferlay J, Soerjomataram I, Siegel RL, Torre LA, Jemal A. Global cancer statistics 2018: GLOBOCAN estimates of incidence and mortality worldwide for 36 cancers in 185 countries. CA Cancer J Clin. 2018;68(6):394-424.

3. Hartaningsih NMD, Sudarsa IW. Kanker Payudara Pada Wanita Usia Muda di Bagian Bedah Onkologi Rumah Sakit Umum Pusat Sanglah Denpasar Tahun 2002 - 2012. E-Jurnal Medika Udayana. 2014;3(6):1-13

4. Peto J, Collins N, Barfoot R, Seal S, Warren W, Rahman N, et al. Prevalence of BRCA1 and BRCA2 gene mutations in patients with early-onset breast cancer. J Natl Cancer Inst. 1999;91(11):943-9

5. Lestari AAW, Prabawa IPY, Wiranata S, Supadmanaba IGP. High eosinophils lymphocyte ratio (ELR) related with subtype of breast cancer in Sanglah General Hospital, Bali. Annals of Oncology. 2018;29(Suppl 9):ix11-ix12

6. Wiranata S, Adiputra PAT, Lestari AAW, Prabawa IPY, Supadmanaba IGP. Platelet Lymphocyte Ratio (PLR) Related with Clinicopathological Characteristics of Balinese Women Breast Cancer Patient. 2019;30(Suppl 6):vi144

7. Kim Y, Yoo KY, Goodman MT. Differences in incidence, mortality and survival of breast cancer by regions and countries in Asia and Contributing Factors. Asian Pac J Cancer Prev. 2015;16(7):2857-70.

8. Khokher S, Qureshi MU, Mahmood S, Sadiq S. Determinants of Advanced Stage at Initial Diagnosis of Breast Cancer in Pakistan: Adverse Tumor Biology vs Delay in Diagnosis. Asian Pac J Cancer Prev. 2016;17(2):759-65

9. Nugraha IMSS, Utami NMS, Affandi Y, Samsarga GW, Manuaba IBT. Pengetahuan Tentang SADARI pada Pasien Kanker Payudara (CAMAMMAE) di Rumah Sakit Umum Pusat Sanglah dan Rumah Sakit Prima Medika Bali November 2012. Intisari Sains Medis. 2013;3(1):23-25 
10. Galukande M, Mirembe F, Wabinga H.Patient Delay in Accessing Breast Cancer Care in a Sub Saharan African Country:Uganda. BrJ Med Med Res. 2014;4(13):2599-2610.

11. Seneviratne S, Lawrenson R, Harvey V, Ramsaroop R, Elwood M, Scott N, et al. Stage of breast cancer at diagnosis in New Zealand: impacts of socio-demographic factors, breast cancer screening and biology. BMC Cancer. 2016;16:129.

12. Partini PDO, Niryana IW, Adiputra PAT. Karakteristik kanker payudara usia muda di Subbagian Bedah Onkologi Rumah Sakit Umum Pusat Sanglah tahun 2014-2016. Intisari Sains Medis. 2018;9(1):76-79

13. Clegg-Lamptey J, Dakubo J, Attobra Y. During treatment in Ghana? A pilot study. Ghana Medical Journal. 2009;43(3):127-132
14. Erku DA. Complementary and Alternative Medicine Use and Its Association with Quality of Life among Cancer Patients Receiving Chemotherapy in Ethiopia: A CrossSectional Study. Evid Based Complement Alternat Med. 2016;2016:2809875.

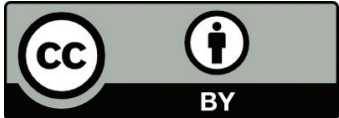

This work is licensed under a Creative Commons Attribution 